\title{
Fungal cell wall agents and bacterial lipopolysaccharide in organic dust as possible risk factors for pulmonary sarcoidosis
}

\author{
Sanja Stopinšek ${ }^{1}$, Alojz Ihan ${ }^{1}$, Barbara Salobir ${ }^{2}$, Marjeta Terčelj ${ }^{2}$ and Saša Simčičč ${ }^{*}$
}

\begin{abstract}
Background: Composition of organic dust is very complex, involving particles of microbial, animal and plant origin. Several environmental exposure studies associate microbial cell wall agents in organic dust with various respiratory symptoms and diseases. The aim of the present study was to investigate the in vitro effects of the co-exposure of fungal cell wall agents (FCWAs) and bacterial lipopolysaccharide (LPS) on inflammatory immune responses of peripheral blood mononuclear cells (PBMCs) from patients with pulmonary sarcoidosis.

Methods: PBMCs from 22 patients with pulmonary sarcoidosis and 20 healthy subjects were isolated and stimulated in vitro with FCWAs (soluble and particulate $(1 \rightarrow 3)-\beta$-D-glucan, zymosan and chitosan) and/or LPS. Subsequently, cytokines were measured by ELISA and the mRNA expression of dectin-1, toll-like receptor 2 (TLR2), TLR4 and mannose receptor (MR) was analysed by real-time RT-PCR.

Results: Patients with sarcoidosis had a significantly higher secretion of inflammatory cytokines tumour necrosis factor-alpha (TNF-a), interleukin-6 (IL-6), IL-10 and IL-12 (1.7-fold, 2.0-fold, 2.2-fold, and 2.8-fold, respectively; all $p<0.05)$ after in vitro co-stimulation of PBMCs with FCWAs and LPS. We showed that PBMCs from patients with sarcoidosis had a higher baseline mRNA expression of dectin-1, TLR2, TLR4 and MR (6-fold, 11-fold, 18-fold, and 4-fold, respectively). Furthermore, we found a reduced expression of dectin-1, TLR2 and TLR4 after stimulation with FCWAs and/or LPS, although the reduction was significantly weaker in patients than in healthy subjects.

Conclusions: In conclusion, co-stimulation with FCWAs and LPS of PBMC from patients with sarcoidosis caused a weaker reduction of dectin-1, TLR2, TLR4 receptors expression, which could increase the sensitivity of PBMCs, leading to excessive inflammatory cytokine responses and result in the development or progression of pulmonary sarcoidosis.
\end{abstract}

Keywords: Sarcoidosis, Fungi, (1 $\rightarrow$ 3)- $\beta$-D-glucan, LPS, PBMC, Cytokines, Pattern-recognition receptors

\section{Background}

Several environmental exposure studies at workplaces or at homes associate microbial cell wall agents in organic dust with various respiratory symptoms and diseases, although, the immunopathological events involved in these diseases are very complex and not well understood. We hypothesized that exposure to fungal cell wall agents (FCWAs) and bacterial lipopolysaccharide (LPS)

\footnotetext{
* Correspondence: sasa.simcic@mf.uni-lj.si

${ }^{1}$ Institute of Microbiology and Immunology, Faculty of Medicine, University of Ljubljana, Zaloška 4, SI-1000 Ljubljana, Slovenia

Full list of author information is available at the end of the article
}

in organic dust may represent a risk factor for pulmonary sarcoidosis development or progression.

Sarcoidosis is a chronic granulomatous disease that most commonly affects the mediastinal lymph nodes and lungs [1]. Despite intensive research, the aetiology of sarcoidosis remains unknown. Terčelj et al. proposed a hypothesis that microbial cell wall agents, particularly agents from moulds, even in the absence of clinical infections can cause a late hypersensitivity reaction leading to granulomas [2]. In support of this hypothesis, several epidemiological studies describe the association between sarcoidosis and living in a damp and mouldy 
environment [3-8]. Furthermore, in clinical studies in which sarcoidosis was treated with antifungals, greater clinical improvement was reported compared with corticosteroid treatment $[9,10]$.

Composition of organic dust is very complex, involving particles of microbial, animal and plant origin. In mice models organic dust exposures induced the development of lymphoid aggregates, peribronchiolar or vascular inflammation, comprised of $\mathrm{T}$ and $\mathrm{B}$ lymphocytes and macrophages with associated neutrophil recruitment [11]. It has been shown that exposure to high levels of fungi and their components present in organic dust represents a risk factor for developing various respiratory symptoms and diseases, such as asthma, hypersensitivity pneumonitis, sick building syndrome and organic dust toxic syndrome [12-14]. Furthermore, bioaerosols with fungi are known to be associated with granulomatous diseases $[4,7,15]$.

Bacterial LPS is one of the prime constituent in organic dust. Inhalation studies showed that LPS can cause cough, dyspnoea, nose and throat irritation, mild fever, flu-like symptoms, acute air flow obstruction, airway inflammation or asthma [16]. Furthermore, adverse effects from LPS may also be increased by other dampness-associated agents [17].

In our previous study we focused on the in vitro and in vivo effects of FCWAs in sarcoidosis. The induced in vitro secretion of cytokines from human peripheral blood mononuclear cells (PBMCs) was higher from subjects with sarcoidosis than from controls. A significant relationship was observed between disease severity, measured as chest X-ray scores indicating granuloma infiltration, and the particulate $(1 \rightarrow 3)$ - $\beta$-D-glucan-induced secretion of cytokines [18-20]. The aim of the present study was to investigate the in vitro effects of the coexposure of FCWAs and LPS on inflammatory immune responses of PBMCs from patients with sarcoidosis. We evaluated the FCWAs influence on the in vitro cellular cytokine response to an inflammatory challenge with LPS in sarcoidosis and on the mRNA expression of the main pattern-recognition receptors (PRRs) for recognizing FCWAs and LPS, dectin-1, toll-like receptor 2 (TLR2), TLR4 and mannose receptor (MR).

\section{Methods}

\section{Subjects}

The study group consisted of 22 patients newly diagnosed with pulmonary sarcoidosis stage II and III according to the established criteria by the American Thoracic Society (ATS), European Respiratory Society (ERS) and World Association of Sarcoidosis and Other Granulomatous Disorders (WASOG) [21], recruited at the Department for Respiratory and Allergic Diseases, University Medical Centre Ljubljana, Slovenia in the period from September 2008 to January 2012. Patient characteristics are shown in Table 1. The exclusion criteria were pulmonary sarcoidosis stage I and IV, CD4/ CD8 ratio in the bronchoalveolar lavage (BAL) less than 4, smoking and receiving any immunosuppressive therapy.

The control group consisted of 20 healthy blooddonor volunteers without any respiratory symptoms or diseases, autoimmune diseases or acute infections. The study was approved by the National Medical Ethics Committee of the Republic of Slovenia (number 122/11/ 08) and written informed consent was obtained from all the participants.

\section{Reagents and preparation of FCWAs and LPS}

All reagents were commercially obtained from SigmaAldrich Corp. (USA), unless otherwise stated. Reagents and FCWAs were endotoxin-free and were prepared exactly as previously described [18]. Briefly, the soluble and the particulate forms of $(1 \rightarrow 3)-\beta$-D-glucan (BGS and BGP) consisted of curdlan from Alcaligenes faecalis var. myxogenes (Wako Pure Chemical Industries, Japan). BGS was prepared from a suspension of curdlan powder in $0.3 \mathrm{M}$ sodium hydroxide $(\mathrm{NaOH})$ heated at $80{ }^{\circ} \mathrm{C}$ in a water bath until completely dissolved. The pH of BGS was neutralized with $0.3 \mathrm{M}$ hydrochloric acid before being added to cell cultures. Curdlan resuspended in RPMI-1640 medium supplemented with $25 \mathrm{mM}$ Hepes buffer (RPMI-1640 medium) represented BGP. Zymosan A from S. cerevisiae (ZYM) was prepared from a suspension of ZYM powder, boiled in $0.25 \mathrm{M} \mathrm{NaOH}$ and resuspended as a $7.5 \mathrm{mg} / \mathrm{ml}$ stock solution in RPMI 1640 medium. A low molecular weight (Mw 50-190 kDa) chitosan from crab shells (75-85 \% deacetylated chitosan, CHT) was prepared as a $2 \mathrm{mg} / \mathrm{ml}$ stock

\section{Table 1 Patient and healthy subject characteristics}

\begin{tabular}{lll}
\hline Characteristic & Sarcoidosis patients & Healthy subjects \\
\hline $\mathrm{N}$ & 22 & 20 \\
Gender & & \\
$\quad$ female & 12 & 13 \\
$\quad$ male & 10 & 7 \\
Age in years mean (range) & $44.7(28-57)$ & $39.9(25-52)$ \\
Smoking & No & No \\
CD4/CD8 ratio in BAL mean (SD) & $7.5(3.0)$ & \\
Chest X-ray & & \\
Stage I & 0 & \\
Stage II & 15 & \\
Stage III & 7 & None \\
Stage IV & 0 & \\
Therapy & None & \\
\hline & &
\end{tabular}


solution in $0.2 \%$ acetic acid. The final concentration in the cell cultures of all FCWAs was $200 \mu \mathrm{g} / \mathrm{ml}$. LPS from Escherichia coli (strain 0111:B4) was dissolved as a $1 \mathrm{mg} /$ $\mathrm{ml}$ stock solution in water and further diluted in a cell culture medium to the final concentration of $10 \mathrm{ng} / \mathrm{ml}$.

\section{Isolation and stimulation of PBMCs}

The model that we previously described was used for in vitro stimulation of PBMCs [18]. Briefly, PBMCs from patients with sarcoidosis and healthy subjects were isolated from freshly drawn venous blood with EDTA by density gradient centrifugation with Ficoll-Paque ${ }^{\mathrm{m}}$ (GE Healthcare, UK). The cells were cultured in RPMI-1640 medium supplemented with $100 \mathrm{U} / \mathrm{ml}$ penicillin, $100 \mu \mathrm{g} / \mathrm{ml}$ streptomycin, $2 \mathrm{mM} \mathrm{L}$-glutamine and $10 \%$ heat-inactivated human serum (Sigma-Aldrich Corp., USA). The $1 \times 10^{6}$ cells (final culture volume of $1.5 \mathrm{ml}$ ) were seeded in 24-well culture plates (Corning Costar, USA) with medium alone, with LPS $(10 \mathrm{ng} / \mathrm{ml})$, with FCWAs, or with LPS and FCWAs at $37{ }^{\circ} \mathrm{C}$ in a humidified atmosphere of $5 \% \mathrm{CO}_{2}$ in air. The cell-free supernatants were collected after 4 and $18 \mathrm{~h}$ of incubation and stored at $-30{ }^{\circ} \mathrm{C}$ before further analysis.

For mRNA expression studies, $1.2 \times 10^{5}$ PBMCs (final culture volume of $180 \mu \mathrm{l}$ ) were plated in 96-well culture plates (Greiner Bio-One GmbH, Germany) in medium alone or with FCWAs $(200 \mu \mathrm{g} / \mathrm{ml})$ in the absence or presence of LPS $(10 \mathrm{ng} / \mathrm{ml})$ at $37{ }^{\circ} \mathrm{C}$ in a humidified atmosphere of $5 \% \mathrm{CO}_{2}$ in air for $4 \mathrm{~h}$.

\section{Real-time reverse transcription polymerase chain reaction (RT-PCR)}

The mRNA expression studies were performed as previously described [18]. Briefly, the total cellular RNA was extracted on an ABI Prism 6100 Nucleic Acid PrepStation (Applied Biosystems, Foster City, USA) according to the manufacturer's instructions. RNA was eluted in $150 \mu \mathrm{l}$ of elution solution and stored at $-80{ }^{\circ} \mathrm{C}$ until required. Ten microliters of total RNA was reverse transcribed in a $27 \mu \mathrm{l}$ reaction mixture with a High Capacity cDNA Reverse Transcription kit (Applied Biosystems) according to the manufacturer's instructions on an ABI GeneAmp PCR System. Real-time PCR was performed on an ABI StepOnePlus Realtime PCR instrument using a TaqMan ${ }^{\circ}$ Universal PCR Master Mix with predeveloped TaqMan Gene Expression Assay primers and probes (Dectin-1 Hs00224028_m1, TLR2 Hs00610101_m1, TLR4 Hs01060206_m1 and MR Hs00267207_m1), according to the manufacturer's instructions (Applied Biosystems). The internal endogenous control used was $18 \mathrm{~S}$ rRNA. Quantification was performed with the comparative $2^{-\Delta \Delta C t}$ method [22]. The amount of target gene was normalized to the internal control gene (18S rRNA) and the relative expression of target genes in cultured PBMCs was calculated in relation to the mean values of target gene expression in healthy subjects after $4 \mathrm{~h}$ of incubation in medium alone.

\section{Cytokine measurements}

Cytokine concentrations in cell culture supernatants were measured by commercially available enzyme-linked immunosorbent assay (ELISA) kits. Tumour necrosis factor-alpha (TNF- $\alpha$ ) (Milenia Biotec, Germany) was measured after $4 \mathrm{~h}$ of incubation. The concentrations of interleukin-6 (IL-6), IL-10 and IL-12 (Thermo Scientific, USA) were measured after $18 \mathrm{~h}$ of incubation.

\section{Statistical analysis}

All statistical analyses were performed using PSAW/ SPSS for Windows version 18 (SPSS Inc., IBM Company, USA). Results are presented as the mean $+/-$ standard error of the mean (SEM). Statistically significant differences in cytokine concentration or in mRNA gene expression between the two groups of subjects were estimated by the nonparametric Mann-Whitney test. $P$ values less than 0.05 were considered statistically significant.

\section{Results}

In vitro inflammatory cytokine response to FCWAs and LPS by PBMCs from patients with sarcoidosis

After co-stimulation of PBMCs with FCWAs and LPS, the production of TNF- $\alpha$, IL- 6 , IL-10 and IL-12 was significantly higher in patients with sarcoidosis, compared to healthy subjects (1.7-fold, 2.0-fold, 2.2-fold, and 2.8 -fold, respectively; all $p<0.05$ ) (Fig. 1). Fold changes are mean values calculated from all four combinations of FCWAs and LPS. Patients with sarcoidosis thus elicited higher levels of in vitro inflammatory cytokine response of PBMCs after co-stimulation with FCWAs and LPS than healthy subjects.

PBMCs mRNA expression of dectin-1, TLR2, TLR4, and MR at baseline and after in vitro stimulation with FCWAs and/ or LPS in patients with sarcoidosis

As shown in Fig. 2, baseline dectin-1, TLR2, TLR4 and MR mRNA expression in PBMCs was higher in patients with sarcoidosis than in healthy subjects (6-fold, 11-fold, 18-fold, and 4-fold, respectively).

When PBMCs were stimulated with FCWAs and/or LPS the mRNA expression of dectin-1, TLR2 and TLR4 was lower than at baseline in both groups of subjects. However, the expression was significantly higher in patients compared to healthy, indicating a weaker reduction of PRRs expression upon FCWAs and/or LPS stimulation in patients with sarcoidosis. Similar results were obtained after 4 and $18 \mathrm{~h}$ of incubation (data not shown). 


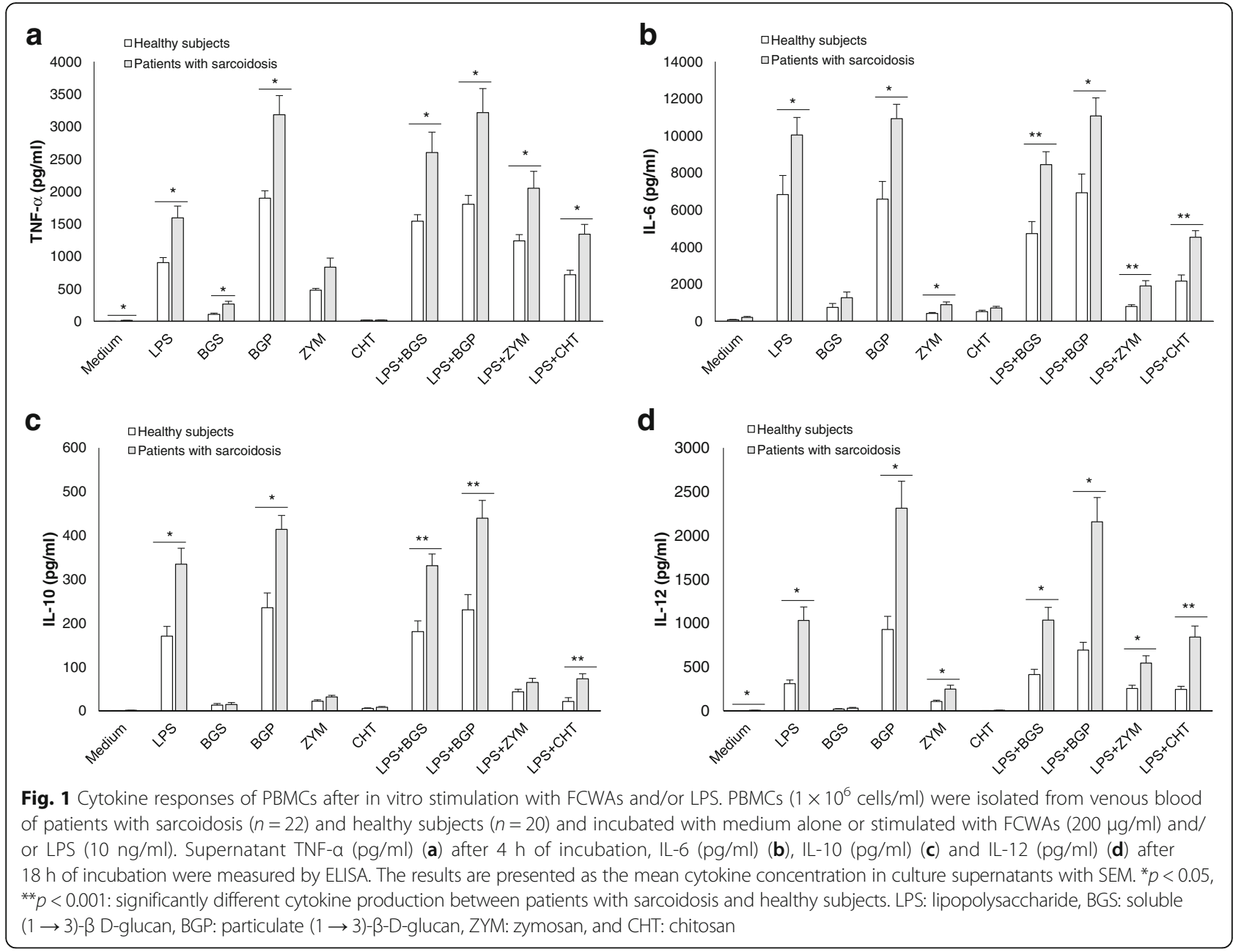

\section{Discussion}

This study was designed to investigate the in vitro effects of the co-exposure of FCWAs and LPS on inflammatory immune responses of PBMCs from patients with sarcoidosis. The main results obtained from this study show that patients with sarcoidosis had a significantly higher secretion of inflammatory cytokines TNF- $\alpha$, IL- 6 , IL-10 and IL-12 after in vitro co-stimulation of PBMCs with FCWAs and LPS. We showed that PBMCs from patients with sarcoidosis had a higher mRNA expression of dectin-1, TLR2, TLR4 and MR at baseline. Furthermore, we found a reduced expression of dectin-1, TLR2 and TLR4 after stimulation with FCWAs and/or LPS, although the reduction was significantly weaker in patients than in healthy subjects.

The organic dust we breathe contains particles of animal, plant and microbial origin, of which the most important in relation to respiratory diseases are fungal $(1 \rightarrow 3)-\beta$-D-glucan and bacterial LPS [14]. We demonstrated previously that after in vitro stimulation of PBMCs with FCWAs alone, the secretion of TNF- $\alpha$, IL6 , IL-10 and IL-12 was higher in patients with sarcoidosis compared to healthy subjects [20]. These cytokines have all been implicated in the immunopathogenesis of sarcoidosis [1, 23-25]. Since FCWAs and LPS might have a synergistic effect on the immune responses of patients with sarcoidosis, we investigated in the present study the in vitro synthesis of inflammatory cytokines in PBMCs after co-stimulation with FCWAs and LPS. Our results showed that patients with sarcoidosis, compared to healthy subjects, had a significantly higher secretion of inflammatory cytokines TNF- $\alpha$, IL-6, IL-10 and IL-12, after co-stimulation of PBMCs with FCWAs and LPS. However, it should be noted that patients with sarcoidosis included in this study had an ongoing inflammatory disease, which may have influenced the immune responses in our in vitro experiments.

In addition to having a strong impact on in vitro human PBMCs inflammatory cytokine responses, FCWAs have been shown to have various biological and immunopharmacological properties (reviewed in [26, 27]). A causal role in the development of respiratory symptoms and diseases associated with fungal exposure has been attributed to $\beta$-glucan $[12,28,29]$. $\beta$-glucan has also 


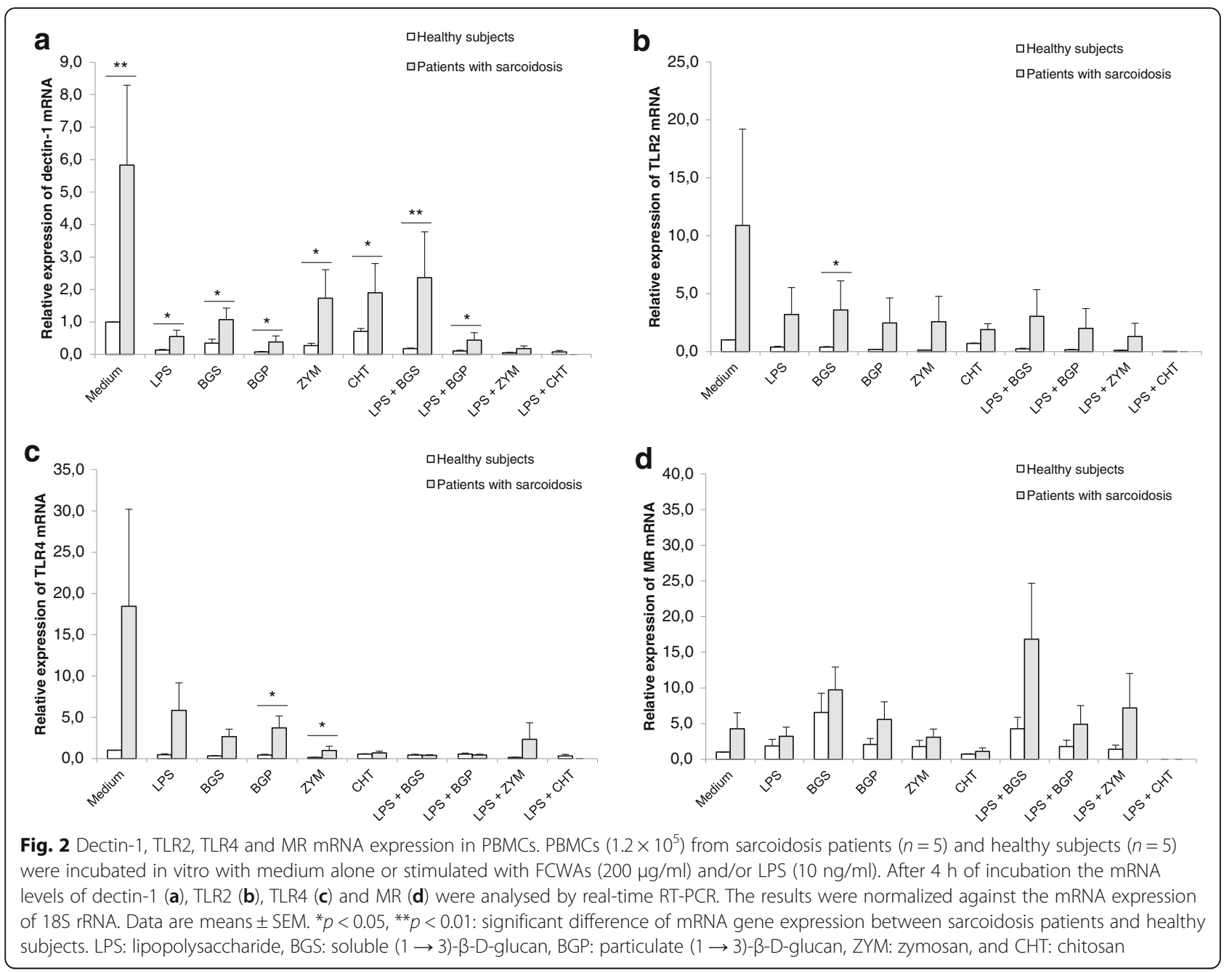

been shown to trigger rheumatoid arthritis in genetically susceptible mice, suggesting that fungal infection may evoke autoimmune conditions in genetically susceptible individuals [30]. Chitin has also been implicated in asthma and allergy [31]. Furthermore, it has been demonstrated that fungi $[4,32,33]$ or $(1 \rightarrow 3)-\beta$-D-glucan itself $[34,35]$ can trigger granuloma formation. In view of all this, we speculated that FCWAs in combination with LPS may evoke an exaggerated inflammatory reaction in genetically susceptible individuals and lead to sarcoid granuloma formation or progression of the disease.

Recent genetic studies suggest that PRRs might be involved in the pathogenesis of sarcoidosis [36-43]. The central PRRs involved in the recognition of fungi are Ctype lectin receptors, such as dectin-1 and MR; TLRs, such as TLR-2, -4 and -9 ; and the galectin family proteins [44]. The key receptor involved in bacterial LPS recognition is TLR4 [45]. All biological activities of $(1 \rightarrow 3)-\beta$-D-glucan are mediated by dectin- 1 , which also collaborates with TLR2 and TLR4. On the other hand, the immunomodulating effects of chitin and its derivatives are mediated by pathways that involve TLR2, dectin- 1 and MR [46]. In our previous study, we examined the in vitro effects of FCWAs alone or in combination with LPS on PRRs mRNA expression in healthy subjects [18]. Since these receptors are suspected of being involved in the pathogenesis of sarcoidosis, we examined the effects of FCWAs and/or LPS on the mRNA expression of these receptors in PBMCs from patients with sarcoidosis.

Our results demonstrated that PBMCs from patients with sarcoidosis had a higher in vitro baseline mRNA expression of dectin-1, TLR2, TLR4 and MR than healthy subjects. The results are in accordance with Wiken et al. [37], who found that TLR2 and TLR4 expression on peripheral blood monocytes at baseline was significantly higher in patients with sarcoidosis than in healthy subjects, as measured by flow cytometry. We found a reduced expression of dectin-1, TLR2 and TLR4 after stimulation with FCWAs and/or LPS, although the reduction was significantly weaker in patients than in healthy subjects. That may indicate a defect in down-regulation of PRRs in sarcoidosis patients when exposed to FCWAs and/or LPS. 


\section{Conclusions}

In conclusion, microbial cell wall agents are airborne and poorly degradable antigens to which we are constantly exposed. Our study demonstrated that co-stimulation with FCWAs and LPS of PBMC from patients with sarcoidosis caused a weaker reduction of dectin-1, TLR2, TLR4 receptors expression, which could increase the sensitivity of PBMCs, leading to excessive inflammatory cytokine responses and result in the development or progression of pulmonary sarcoidosis.

\section{Abbreviations}

BGP: Particulate $(1 \rightarrow 3)-\beta-D-g l u c a n ;$ BGS: Soluble $(1 \rightarrow 3)-\beta-D-g l u c a n$; CHT: Chitosan; FCWAs: Fungal cell wall agents; IL: Interleukin;

LPS: Lipopolysaccharide; MR: Mannose receptor; PBMCs: Peripheral blood mononuclear cells; PRRs: Pattern-recognition receptors; TLR: Toll-like receptor; TNF-a: Tumour necrosis factor-alpha; ZYM: Zymosan A

\section{Acknowledgements}

The authors thank Professor Ragnar Rylander and Senior Research Fellow Branka Wraber for their invaluable constructive cooperation in the study.

\section{Funding}

This study was supported by a grant from the Slovenian Research Agency, Program Number P3-0083-0381, and by a grant from the Ministry of Higher Education, Science and Technology of the Republic of Slovenia (doctoral fellowship).

\section{Availability of data and materials}

The datasets during and/or analysed during the current study available from the corresponding author on reasonable request.

\section{Authors' contributions}

SS substantially contributed to the concept and design of the study, experimental work (PBMCs cultures, cytokine measurements, gene expression assays), analysis of the results and writing of the manuscript. Al substantially contributed to the concept and design of the study, analysis of the results and writing of the manuscript. BS substantially contributed to the concept and design of the study, experimental work (selection of patients), analysis of the results and writing of the manuscript. MT substantially contributed to the concept and design of the study, experimental work (selection of patients), analysis of the results and writing of the manuscript. SS substantially contributed to the concept and design of the study, experimental work (PBMCs cultures, cytokine measurements, gene expression assays), analysis of the results and writing of the manuscript. All authors read and approved the final manuscript.

\section{Competing interests}

The authors declare they have no competing interest.

\section{Consent for publication}

Not applicable.

\section{Ethics approval and consent to participate}

The study was approved by the National Medical Ethics Committee of the Republic of Slovenia (number 122/11/08) and written informed consent was obtained from all the participants.

\section{Author details}

${ }^{1}$ Institute of Microbiology and Immunology, Faculty of Medicine, University of Ljubljana, Zaloška 4, SI-1000 Ljubljana, Slovenia. ${ }^{2}$ Department for Respiratory and Allergic Diseases, University Medical Centre, Zaloška 2, SI-1000 Ljubljana, Slovenia.

Received: 19 July 2016 Accepted: 17 September 2016 Published online: 21 September 2016

\section{References}

1. Baughman RP, Culver DA, Judson MA. A concise review of pulmonary sarcoidosis. Am J Respir Crit Care Med. 2011;183:573-81.

2. Tercelj M, Salobir B, Rylander R. Microbial antigen treatment in sarcoidosis-a new paradigm? Med Hypotheses. 2008;70:831-4.

3. Kucera GP, Rybicki BA, Kirkey KL, Coon SW, Major ML, Maliarik MJ, et al. Occupational risk factors for sarcoidosis in African-American siblings. Chest. 2003;123:1527-35.

4. Newman LS, Rose CS, Bresnitz EA, Rossman MD, Barnard J, Frederick M, et al. A case control etiologic study of sarcoidosis: environmental and occupational risk factors. Am J Respir Crit Care Med. 2004;170:1324-30.

5. Cox-Ganser JM, White SK, Jones R, Hilsbos K, Storey E, Enright PL, et al. Respiratory morbidity in office workers in a water-damaged building. Environ Health Perspect. 2005;113:485-90.

6. Dangman $\mathrm{KH}$, Bracker AL, Storey E. Work-related asthma in teachers in Connecticut: association with chronic water damage and fungal growth in schools. Conn Med. 2005:69:9-17.

7. Laney AS, Cragin LA, Blevins LZ, Sumner AD, Cox-Ganser JM, Kreiss K, et al. Sarcoidosis, asthma, and asthma-like symptoms among occupants of a historically water-damaged office building. Indoor Air. 2009;19:83-90.

8. Tercelj M, Salobir B, Harlander M, Rylander R. Fungal exposure in homes of patients with sarcoidosis - an environmental exposure study. Environ Health. 2011:10:8.

9. Tercelj M, Rott T, Rylander R. Antifungal treatment in sarcoidosis-a pilot intervention trial. Respir Med. 2007;101:774-8.

10. Tercelj M, Salobir B, Zupancic M, Rylander R. Antifungal medication is efficient in the treatment of sarcoidosis. Ther Adv Respir Dis. 2011;5:157-62.

11. Dusad A, Thiele GM, Klassen LW, Gleason AM, Bauer C, Mikuls TR, et al. Organic dust, lipopolysaccharide, and peptidoglycan inhalant exposures result in bone loss/disease. Am J Respir Cell Mol Biol. 2013;49:829-36.

12. Douwes J. (1->3)-Beta-D-glucans and respiratory health: a review of the scientific evidence. Indoor Air. 2005;15:160-9.

13. Norback D. An update on sick building syndrome. Curr Opin Allergy Clin Immunol. 2009:9:55-9.

14. Rylander R. Organic dust induced pulmonary disease - the role of mould derived beta-glucan. Ann Agric Environ Med. 2010;17:9-13.

15. Rose CS, Martyny JW, Newman LS, Milton DK, King Jr TE, Beebe JL, et al. "Lifeguard lung": endemic granulomatous pneumonitis in an indoor swimming pool. Am J Public Health. 1998;88:1795-800.

16. Vetvicka V, Novak M. Biology and Chemistry of Beta Glucan: Beta Glucans Mechanisms of Action. Vol 1. Bussum: Bentham Science Publishers; 2011.

17. Kanchongkittiphon W, Mendell MJ, Gaffin JM, Wang G, Phipatanakul W. Indoor environmental exposures and exacerbation of asthma: an update to the 2000 review by the Institute of Medicine. Environ Health Perspect. 2015;123:6-20.

18. Stopinsek S, Ihan A, Wraber B, Tercelj M, Salobir B, Rylander R, et al. Fungal cell wall agents suppress the innate inflammatory cytokine responses of human peripheral blood mononuclear cells challenged with lipopolysaccharide in vitro. Int Immunopharmacol. 2011;11:939-47.

19. Stopinsek S, Tercelj M, Salobir B, Wraber B, Ihan A, Rylander R, et al. Effects of fungal cell wall polysaccharides and lipopolysaccharide on in vitro tumor necrosis factor alpha production by peripheral blood mononuclear cells of sarcoidosis patients. Zdrav Vestn. 2010;79:684-9.

20. Tercelj M, Stopinsek S, Ihan A, Salobir B, Simcic S, Wraber B, et al. In vitro and in vivo reactivity to fungal cell wall agents in sarcoidosis. Clin Exp Immunol. 2011;166:87-93.

21. Statement on sarcoidosis. Joint Statement of the American Thoracic Society (ATS), the European Respiratory Society (ERS) and the World Association of Sarcoidosis and Other Granulomatous Disorders (WASOG) adopted by the ATS Board of Directors and by the ERS Executive Committee, February 1999 Am J Respir Crit Care Med. 1999;160:736-55.

22. Livak KJ, Schmittgen TD. Analysis of relative gene expression data using real-time quantitative PCR and the 2(-Delta Delta C(T)) Method. Methods. 2001;25:402-8.

23. Gerke AK, Hunninghake G. The immunology of sarcoidosis. Clin Chest Med. 2008;29:379-90. vii.

24. Clementine RR, Lyman J, Zakem J, Mallepalli J, Lindsey S, Quinet R. Tumor necrosis factor-alpha antagonist-induced sarcoidosis. J Clin Rheumatol. 2010;16:274-9.

25. Zissel G. Cellular activation in the immune response of sarcoidosis. Semin Respir Crit Care Med. 2014;35:307-15. 
26. Brown GD, Herre J, Williams DL, Willment JA, Marshall AS, Gordon S Dectin-1 mediates the biological effects of beta-glucans. J Exp Med. 2003;197:1119-24

27. Muzzarelli RA. Chitins and chitosans as immunoadjuvants and nonallergenic drug carriers. Mar Drugs. 2010;8:292-312.

28. Fogelmark B, Sjostrand M, Rylander R. Pulmonary inflammation induced by repeated inhalations of beta(1,3)-D-glucan and endotoxin. Int J Exp Pathol. 1994;75:85-90

29. Rylander R, Lin RH. (1-> 3)-beta-D-glucan - relationship to indoor air-related symptoms, allergy and asthma. Toxicology. 2000;152:47-52.

30. Yoshitomi H, Sakaguchi N, Kobayashi K, Brown GD, Tagami T, Sakihama T, et al. A role for fungal \{beta\}-glucans and their receptor Dectin-1 in the induction of autoimmune arthritis in genetically susceptible mice. J Exp Med. 2005;201:949-60.

31. Brinchmann BC, Bayat M, Brogger T, Muttuvelu DV, Tjonneland A, Sigsgaard T. A possible role of chitin in the pathogenesis of asthma and allergy. Ann Agric Environ Med. 2011;18:7-12.

32. Martin 2nd WJ, lannuzzi MC, Gail DB, Peavy HH. Future directions in sarcoidosis research: summary of an NHLBI working group. Am J Respir Crit Care Med. 2004;170:567-71.

33. Ezzie ME, Crouser ED. Considering an infectious etiology of sarcoidosis. Clin Dermatol. 2007:25:259-66.

34. Gallin EK, Green SW, Patchen ML. Comparative effects of particulate and soluble glucan on macrophages of $\mathrm{C} 3 \mathrm{H} / \mathrm{HeN}$ and $\mathrm{C} 3 \mathrm{H} / \mathrm{HeJ}$ mice. Int J Immunopharmacol. 1992;14:173-83.

35. Tanaka K, Morimoto J, Kon S, Kimura C, Inobe M, Diao H, et al. Effect of osteopontin alleles on beta-glucan-induced granuloma formation in the mouse liver. Am J Pathol. 2004;164:567-75.

36. Schurmann M, Kwiatkowski R, Albrecht M, Fischer A, Hampe J, MullerQuernheim J, et al. Study of Toll-like receptor gene loci in sarcoidosis. Clin Exp Immunol. 2008;152:423-31.

37. Wiken M, Grunewald J, Eklund A, Wahlstrom J. Higher monocyte expression of TLR2 and TLR4, and enhanced pro-inflammatory synergy of TLR2 with NOD2 stimulation in sarcoidosis. J Clin Immunol. 2009;29:78-89.

38. Hattori T, Konno S, Takahashi A, Isada A, Shimizu K, Shimizu K, et al. Genetic variants in mannose receptor gene (MRC1) confer susceptibility to increased risk of sarcoidosis. BMC Med Genet. 2010;11:151.

39. Margaritopoulos GA, Antoniou KM, Karagiannis K, Samara KD, Lasithiotaki I, Vassalou $E$, et al. Investigation of Toll-like receptors in the pathogenesis of fibrotic and granulomatous disorders: a bronchoalveolar lavage study. Fibrogenesis Tissue Repair. 2010;3:20.

40. Veltkamp M, Van Moorsel CH, Rijkers GT, Ruven HJ, Van Den Bosch JM Grutters JC. Toll-like receptor (TLR)-9 genetics and function in sarcoidosis. Clin Exp Immunol. 2010;162:68-74.

41. Wiken M, Idali F, Al Hayja MA, Grunewald J, Eklund A, Wahlstrom J. No evidence of altered alveolar macrophage polarization, but reduced expression of TLR2, in bronchoalveolar lavage cells in sarcoidosis. Respir Res. 2010;11:121

42. Gabrilovich MI, Walrath J, van Lunteren J, Nethery D, Seifu M, Kern JA, et al. Disordered Toll-like receptor 2 responses in the pathogenesis of pulmonary sarcoidosis. Clin Exp Immunol. 2013;173:512-22.

43. Pabst S, Bradler O, Gillissen A, Nickenig G, Skowasch D, Grohe C. Toll-like receptor-9 polymorphisms in sarcoidosis and chronic obstructive pulmonary disease. Adv Exp Med Biol. 2013;756:239-45.

44. Romani L. Immunity to fungal infections. Nat Rev Immunol. 2011;11:275-88.

45. Park BS, Lee JO. Recognition of lipopolysaccharide pattern by TLR4 complexes. Exp Mol Med. 2013:45, e66.

46. Da Silva CA, Hartl D, Liu W, Lee CG, Elias JA. TLR-2 and IL-17A in chitininduced macrophage activation and acute inflammation. J Immunol. 2008;181:4279-86

\section{Submit your next manuscript to BioMed Central and we will help you at every step:}

- We accept pre-submission inquiries

- Our selector tool helps you to find the most relevant journal

- We provide round the clock customer support

- Convenient online submission

- Thorough peer review

- Inclusion in PubMed and all major indexing services

- Maximum visibility for your research

Submit your manuscript at www.biomedcentral.com/submit
Biomed Central 